\title{
Faktor Pendorong Keberangkatan TKI dalam Memenuhi Investasi Non Fisik di Kecamatan Selorejo Kabupaten Blitar Dwi Eko Waluyo ${ }^{1}$ Setyo Wahyu Sulistyono ${ }^{2}$
}

\author{
Fakultas Ekonomi dan Bisnis, Universitas Muhammadiyah Malang ${ }^{1}$
}

\begin{abstract}
Abstrak
Secara teoritis peran investasi non fisik berupa pendidikan dan kesehatan sebagai faktor pendorong (push factor) seseorang menjadi TKI di Kabupaten Malang Provinsi Jawa Timur, dengan metode pengumpulan data untuk memperoleh data primer, sebagai tahap pertama peneliti hadir di Kecamatan Selorejo. Dengan tujuan masalah (1) Menjawab peran investasi non fisik berupa pendidikan sebagai pendorong seseorang menjadi TKI di Kecamatan Selorejo Kabupaten Blitar Provinsi Jawa Timur. (2). Menjawab peran investasi non fisik berupa kesehatan dan pendidikan sebagai pendorong seorang menjadi TKI di Kecamatan Selorejo Kabupaten Blitar Provinsi Jawa Timur . Kabupaten Blitar sebagai situs penelitian sebagai observasi awal, dengan diikuti tahap observasi dengan menggunakan pertanyaan mendalam (deep questions) dengan harapan menjawab secara faktual alasan seorang menjadi TKI secara fenomenalogi diikuti oleh tahapan terakhir berupa collection data, berupa hasil wawancara atau dokumen terkait sebagai pendukung penelitian yang ditujukan kepada mantan TKI atau calon TKI yang pada saat penelitian berada di situs penelitian dengan pendekatan triangulasi data sebagai uji validitas kebenaran dari penelitian. Hasil yang diperoleh dari beberapa responden peran karakter sosial ekonomi informan menjadi TKI senantiasa untuk membantu meringankan beban suami yang memiliki tanggungjawab atas keluarga dan berupaya untuk membiayai pendidikan anak dalam memprioritaskan dalam investasi non fisik dan modal usaha dalam pengembangan usaha suami. Abstract berisi tujuan penelitian, metodologi dan ringkasan hasil utama penelitian. Abstract ditulis dalam bahasa Inggris dan mengikuti format dalam template ini. Peneliti diharapkan melakukan copy dan format painter untuk memasukkan abstract mereka maupun hasil penelitian. Keywords: Integrity, Phenomenology, Public Accountant
\end{abstract}

\section{Pendahuluan}

Secara makro, krisis ekonomi yang dialami oleh bangsa Indonesia membawa dampak luas terhadap Kabupaten /Kota di Jawa Timur, terutama pada permintaan dan penawaran agregat. Menurut Purwanti (2009), dampak pada penawaran dan permintaan agregat dapat dilihat pada pasar tenagakerja. Pada pasar tenagakerja, dampak tersebut antara lain: (a) jumlah dan persentase tenaga kerja di sektor formal yang beberapa terdiri dari sektor industri dan jasa yang menurun, (b) tingkat pengangguran penuh dan setengah pengangguran yang meningkat, dan (c) tingkat ketergantungan pada sektor informal yang semakin besar. Keseluruhan dampak ini mencerminkan kelesuan pasar tenaga kerja di Kabupaten/Kota di Jawa Timur, yang pada gilirannya menyebabkan cenderung menurunnya pendapatan para pekerja sehingga dengan suatu alasan tertentu saat akan menyebabkan perpindahan tenaga kerja dari suatu wilayah kenegaraan tertentu dan memilih menjadi tenaga kerja Indonesia yang melakukan perpindahan ke luar negeri, dan menjadi suatu pilihan untuk menjadi tenaga kerja Indonesia.

Investasi dalam suatu perekonomian menunjukkan salah satu pilar pertumbuhan ekonomi. Investasi dapat berupa investasi modal yang berupa fisik maupun investasi modal manusia atau investasi non fisik. Investasi fisik (physical investment) yakni semua pengeluaran yang dapat menciptakan modal baru (Mankiw, 2000:24) atau meningkatkan stok barang modal. Sedangkan investasi non fisik dalam hal ini investasi yang bersifat pengembangan sumber daya manusia (human capital investment) dapat berupa nilai-nilai pembelajaran dan pengalaman yang ada dalam diri tenaga kerja seperti peningkatan produktivitas dan pendapatan. Beberapa bentuk investasi sumber daya manusia dapat berupa pendidikan, kesehatan maupun migrasi. Sumber daya manusia sebagai salah satu faktor produksi selain sumber days alam, modal, entrepreneur untuk menghasilkan output. Semakin tinggi kualitas sumber daya manusia, maka semakin meningkat pula efisiensi dan produktivitas suatu negara. Sejarah mencatat bahwa negara yang menerapkan

\footnotetext{
1 dewa_umm@umm.ac.id
} 
paradigma pembangunan berdimensi manusia telah mampu berkembang meskipun tidak memiliki kekayaan sumber daya alam yang berlimpah. Penekanan pada investasi manusia diyakini merupakan basis dalam meningkatkan produktivitas faktor produksi secara total. Tanah, tenaga kerja, modal fisik bisa saja mengalami diminishing return, namun ilmu pengetahuan tidak. Robert M. Solow menekankan kepada peranan ilmu pengetahuan dan investasi modal sumber daya manusia dalam memacu pertumbuhan ekonomi. teori Solow ini kemudian dikembangkan teori baru pertumbuhan ekonomi yang dikenal sebagai The New Growth Theory. (H. A. R. Tilaar, 2000).

Pentingnya push factor dalam bentuk investasi menjadi suatu hal yang menarik untuk diteliti, dimana dengan pertumbuhan demografi di setiap wilayah regional di Indonesia yang memiliki trend positif sehingga mendorong setiap personal untuk memiliki kemampuan daya saing kemampuan diri sebagai pemenuhan dalam pasar tenaga kerj, apabila ketersediaan tenaga kerja tidak mampu diserap dengan baik oleh penawaran tenaga kerja dalam hal ini tenaga kerja, maka akan mendorong kepada perpindahan wilayah dalam lapangan pekerjaanan atau menjadi TKI. Potensi inilah yang nantinya akan menjadi fenomena ketersediaan tenaga kerja, fenomena lain yang lebih global yang terjadi pada sebagian besar negara di dunia adalah migrasi Internasional dalam hal ini perpindahan tenaga kerja Internasional. Fenomena ini terus berkembang seiring dengan pola hubungan yang terjalin antar negara pengirim dan penerima tenaga kerja Internasional, pesatnya pertumbuhan ekonomi di negara-negara berkembang Asia Pasifik seperti Singapura, Hongkong, Malaysia, Taiwan, dan Korea Selatan dibandingkan kawasan lain menyebab kebutuhan perekonomian semakin meningkat (Prijono Tjiptoherijanto. 2004). Fenomena ini menyambung dari situasi dan kondisi ekonomi Indonesia yang tidak stabil dibarengi dengan ketersediaan lapangan pekerjaan yang tidak mampu menopang kehidupan masyarakat mengakibatkan meningkatnya arus tenaga kerja Indonesia ke negara lain semakin meningkat dan menjadikan suaatu hal yang menarik untuk diteliti.

\section{Tinjauan Pustaka}

\section{Definisi Sumber Daya Manusia dan Manajemen Manusia}

Memahami makna ESDM telah dijelaskan oleh Sumarsono (2003) Ekonomi Sumber Daya Manusia (ESDM) merupakan teori ekonomi pada analisis sumber daya manusia. Pembahasan secara deskriptif maupun analisis, teknis analisis dapat dengan uraian penjelasan grafik dan dengan matematika, sumber daya manusia mengandung dua arti. Pertama), SDM merupakan usaha kerja atau jasa yang dapat diberikan dalam proses produksi, dalam hal ini SDM mencerminkan kualitas usaha yang diberikan oleh seorang dalam waktu tertentu untuk menghasilkan barang dan jasa. Kedua), SDM menyangkut manusia yang mampu bekerja untuk memberikan jasa atau usaha kerja tersebut. Mampu bekerja berarti mampu melakukan kegiatan yang memiliki nilai ekonomis, yaitu bahwa kegiatan tersebut menghasilkan barang dan jasa untuk memenuhi kebutuhan masyarakat.

Manajemen Sumber Daya Manusia (MSDM) merupakan bentuk aplikatif dari ekonomi sumber daya manusia yang diperlukan sebagai bentuk kelola dari permasalah ekonomi, Manajemen sumber daya manusia adalah perencanaan, pengorganisasian, pengarahan dan pengawasan kegiatan-kegiatan, pengadaan, pengembangan, pemberian kompensasi, pengintegrasian, pemeliharaan dan pelepasan sumber daya manusia agar tercapai berbagai tujuan individu, organisasi, dan masyarakat. (Flipo,1989)

\section{Pengertian Tenaga Kerja}

Jawa Timur memiliki potensi tenaga kerja yang besar di mana setiap periode tahun semakin bertambah seiring dengan jumlah kelulusan dari setiap tingkatan pendidikan, tenaga kerja tersebut terbagi menjadi dua yaitu tenaga kerja terlatih dan tidak terlatih , tenaga kerja terlatih diharapkan secara langsung dapat terserap secara baik dalam pasar tenaga kerja dan mampu terserap pula di sektor formal. Payaman Simanjuntak (1998) menjelaskan bahwa tenaga kerja adalah penduduk yang sudah atau sedang bekerja, yang sedang mencari pekerjaan, dan melakukan kegiatan lain seperti bersekolah atau mengurus rumah tangga, dengan batasan umur 15 tahun. Pernyataan ini sejalan dengan pendapat Aris Ananta (1990) dan Ignatia -Nachrowi (2004) yang menyatakan bahwa tenaga kerja adalah sebagian dari keseluruhan penduduk yang secara potensial dapat menghasilkan barang dan jasa.

Sehingga dari pernyataan tersebut dapat disimpulkan bahwa tenaga kerja adalah sebagian penduduk yang dapat menghasilkan barang dan jasa bila terdapat permintaan terhadap barang dan jasa. Penggolongan tenaga kerja menurut Simanjuntak (1998) terdiri atas angkatan kerja dan bukan angkatan kerja. Angkatan kerja terdiri dari (1) golongan yang bekerja, dan (2) golongan yang menganggur dan pencari pekerjaan. Kelompok angkatan kerja terdiri dari (1) golongan yang bersekolah, (2) golongan yang mengurus rumah tangga, dan (3) golongan lain-lain atau penerima pendapatan. Ketiga golongan tersebut menjelaskan tentang tiap golongan yang menawarkan jasanya untuk bekerja.

\section{Teori Migrasi Todaro}


Teori yang menjadi dasar penelitian ini adalah model migrasi Todaro (1998) menyatakan migrasi merupakan suatu proses yang sangat selektif mempengaruhi setiap individu dengan cirri ekonomi, social, pendidikan dan demografi tertentu, maka pengaruhnya terhadap faktor-faktor ekonomi dan non ekonomi dari masing-masing individu juga bervariasi. Model migrasi Todaro menyatakan juga bahwa keputusan migrasi tidak hanya ditentukan oleh berapa upah yang diterima seandainya migrasi dikalukan, tetapi memperhitungkan juga berapa besar peluang untuk mendapatkan pekerjaan. Dengan demikian upah yang besar belum tentu menarik pekerja untuk bermigrasi, sebaliknya upah relative rendah akan cukup menarik calon migran jika peluang untuk mendapatkan relatif besar. Berdasarkan dari asumsi Todaro yang menyebutkan bahwa keputusan migrasi adalah merupakan fenomena yang nasional, bias dikatakan bahwa migrasi tenaga kerja kurang lebih didorong oleh pertimbangan ekonomis. Todaro (1998) menyatakan migrasi merupakan suatu proses yang sangat selektif mempengaruhi setiap individu dengan cirri ekonomi, social, pendidikan dan demografi tertentu, maka pengaruhnya terhadap faktor-faktor ekonomi dan non ekonomi dari masing-masing individu juga bervariasi. antara lain:

Beberapa faktor non ekonomis yang mempengaruhi keinginan seseorang melakukan migrasi

1. Faktor-Faktor social, termasuk keinginan para migrant untuk melepaskan kendala tradisional yang terkandung dalam organisasi-organisasi social yang sebelumnya mengekang mereka.

2. Faktor-faktor fisik, termasuk pengaruh iklim dan bencana meteorologist, seperti banjir dan kekeringan.

3. Faktor-Faktor Demografi, termasuk penurunan tingkat kematian yang kemudian mempercepat laju pertumbuhan penduduk suatu tempat.

4. Faktor-Faktor Kultural, termasuk pembinaan kelestarian hubungan keluarga besar yang berada pada tempat tujuan migrasi.

5. Faktor-faktor komunikasi, termasuk kualitas seluruh sarana transportasi, system pendidikan yang cenderung berorientasi pada kehidupan kota dan dampak-dampak modernisasi yang ditimbulkan oleh media massa atau media elektronik.

\section{Teori Investasi Non-Fisik Sumber Daya Manusia}

Investasi sumber daya manusia adalah suatu biaya yang harus dikorbankan baik dalam bentuk uang, waktu, maupun kesempatan untuk membentuk modal manusia yang lebih baik di masa depan. Sedangkan modal manusia (human capital) adalah istilah yang sering digunakan oleh para ekonom untuk pendidikan, kesehatan, dan kapasitas manusia yang lain yang dapat meningkatkan produktivitas jika halhal tersebut ditingkatkan.Produktivitas yang tinggi akan memacu laju pertumbuhan output secara agregat lebih tinggi (Todaro dan Smith, 2006).

Modal manusia (human capital) adalah salah satu faktor penting yang mendukung perubahan dan pengembangan teknologi, sedangkan teknologi besertainvestasi modal fisik dan jumlah penduduk merupakan fungsi dari pertumbuhan output.Dalam teori pertumbuhan ekonomi baru atau yang disebut sebagai teori pertumbuhan endogen (endogenous growth theory), faktor eksternal dilibatkan sebagai penentu pertumbuhan ekonomi dan modal manusia sebagai salah satu faktor tersebut (Barro dan Martin, 1985). Selain itu, modal manusia merupakan bentuk kemampuan atau skill yang dimiliki seseorang dan menunjukkan kualitas dari individu tersebut. Kualitas sumber daya manusia mampu menjadi nilai jual seseorang di pasar tenaga kerja. Semakin baik kualitassumber daya manusia, maka semakin besar pula permintaan atas tenaga kerja tersebut karena kualitas sumber daya manusia yang baik memiliki produktivitas yang tinggi (Sitepu, 2010).

Dalam pelaksanaan pembangunan wilayah, indikator pertumbuhan ekonomi selalu dijadikan sebagai tolak ukur keberhasilan pembangunan.Pertumbuhan ekonomi merupakan ukuran perkembangan output suatu wilayah selama periode tertentu, sedangkan output tersebut menunjukkan produktivitas suatu willayah akibat adanya suatu investasi.Keputusan berinvestasi tersebut diharapkan dapat memberikan pengembalian yang lebih besar dari biaya investasi yang dikeluarkan. Investasi yang umum dilakukan adalah bentuk investasi fisik dan finansial dalam bidang usaha. Investasi tersebut dilakukan dengan mengorbankan pengeluaran pada suatu periode untuk memperoleh pengeluaran yang lebih besar di periode berikutnya. Akan tetapi, prinsip investasi tersebut tidak hanya dilakukan dalam bentuk fisik, modal, maupun finansial dalam bidang usaha, melainkan investasi di bidang sumber daya manusia. Investasi sumber daya manusia akan membentuk modal manusia (human capital) yang akan memberikan imbalan berupa penghasilan yang lebih besar di masa mendatang.

Sama halnya dengan investasi di bidang usaha tersebut, maka investasi dilakukan juga di bidang sumber daya manusia. Yang dikorbankan adalah sejumlah dana yang dikeluarkan dan kesempatan memperoleh penghasilan selama proses investasi. Yang diperoleh sebagai imbalannya adalah tingkat penghasilan yang lebih tinggi untuk mampu mencapai tingkat pengeluaran yang lebih tinggi pula. Investasi yang demikian dinamakan human capital. Penerapannya dapat dilakukan dalam hal (1) pendidikan dan 
latihan, (2) migrasi, dan (3) perbaikan gizi dan kesehatan (Simanjutak, 1998).

\section{Pendidikan Sebagai Modal Non-Fisik}

Simanjutak (1998) menyatakan bahwa asumsi dasar dari teori human capital adalah bahwa seseorang dapat meningkatkan penghasilannya melalui peningkatan pendidikan. Setiap tambahan satu tahun sekolah, berarti, di satu pihak, meningkatkan kemampuan kerja dan tingkat penghasilan seseorang, akan tetapi, di pihak lain, menunda penerimaan penghasilan selama satuh tahun dalam mengikuti sekolah tersebut. Di samping penundaan menerima penghasilan tersebut, orang melanjutkan sekolah harus membayar biaya secara langsung seperti uang sekolah, pembelian buku-buku, dan alat-alat sekolah, tambahan uang transpor dan lain-lain. Dalam Human Capital: A Theoritical and Empirical Analysis with Special Reference to Education, Becker (1975) menyatakan bahwa jika pelatihan hanya diberikan pada periode awal, pengeluaran pada periode tersebut akan sama dengan upah ditambah biaya pelatihan, sedangkan pengeluaran pada periode lain akan sama dengan upah saja dan penerimaan seluruh periode akan sama dengan marjinal produk

\section{Metodologi \\ Metodologi Penelitian}

Penelitian ini menggunakan metode penelitian kualitatif, yaitu suatu penelitian yang berusaha memecahkan masalah melalui analisis data-data non-numerik. Menurut Marvasti (2004) penelitian kualitatif berusaha memberikan deskripsi yang terperinci dan analisis kualitas (atau hakikat) dari pengalaman manusia. Dengan kata lain, penelitian kualitatif lebih memusatkan perhatiannya pada kedalaman makna pengalaman manusia itu sendiri ketimbang pada realitas kehidupan yang hanya tampak di permukaan.

Sementara itu, penelitian ini dilakukan dalam kerangka paradigma interpretivis (interpretive paradigm), yaitu suatu paradigma yang berusaha memahami gejala sosial sebagaimana adanya. Meskipun demikian, paradigma ini berusaha mencari penjelasan dalam area kesadaran dan subjektivitas individu, dalam kerangka rujukan si partisipan, bukan menurut sudut pandang si pengamat (observer) (Burrell dan Morgan, 1979). Dengan demikian, maka menurut paradigma ini unsur subjektivitas tetap diakui keabsahannya. sebagai unsur yang tak terelakkan dalam penarikan kesimpulan ilmiah. Ketika menjawab ketidakpahaman atas sebuah kenyataan penelitian sosial cenderung akan menghasilkan pemahaman yang berbeda menurut kaca mata, cara pandang atau paradigma yang digunakan. Tingkat keyakinan seorang peneliti atas sebuah paradigma menunjukkan bahwa pendekatan tersebut merupakan pendekatan yang untuk menyajikan kenyataan sosial.

Pada arus pengetahuan sosial, terdapat paradigma yang mengangkat metode ilmu alam sebagai pendekatan untuk menjelaskan kenyataan sosial, yakni mereka yang merujuki pandangan atau paradigma positivisme. Positivisme berasal dari para teoritisi sosial abad kesembilan belas dan awal abad kedua puluh, terutama Auguste Comte dan Emile Durkheim. Penganut positivisme ini mencari fakta atau sebab musabab gejala sosial dengan tidak mempertimbangkan keadaan subyektif individu.

Juga disarankan oleh Durkheim agar ilmuwan sosial menganggap kenyataan sosial atau gejala sosial sebagai sesuatu yang mempunyai pengaruh eksternal dan yang bersifat memaksa terhadap perilaku manusia (Bogdan dan Taylor, 1992). Dari sudut pandang metode penelitian, penekanan Durkheim di atas menunjukkan bahwa peneliti cenderung interventif dalam memperlakukan manusia. Manusia seolah-olah dianggap sebagai makhluk statis, membatasi perilakunya melalui asumsi, membatasi kenyataan/realitas lewat variabel, dan sebagai konsekuensinya manusia dipandang sebagai obyek, perilakunya dimodelkan, dapat dibentuk dan diramalkan, sehingga memberi kemampuan kepada peneliti untuk menyusun simpulan deduktif atau generalisasi.

Sebagaimana telah dikemukakan oleh Parera (2012) menyatakan bahwa dalam kajian sosiologi, yang dikejar oleh sosiolog positivisme adalah hukum-hukum perkembangan masyarakat yang pada gilirannya dapat dikuasai dan diarahkan menurut proyeksi perkembangan seperti model perencanaan di bidang sains dan teknologi. Sementara dari arus pengetahuan yang berlawanan menyatakan bahwa gejala sosial tidak dapat disamakan dengan gejala alam, seperti sains dan teknologi. Arus pengetahuan ini merujuk pada paradigma non-positivisme. Nonpositivisme memandang manusia sebagai makhluk bebas, memiliki keinginan, dan tujuan. Bagi Irwin Deutscher dan Max Weber yang dikutip oleh Bogdan dan Taylor (1992) bahwa paradigma ini dapat dilukiskan sebagai sesuatu yang bersifat fenomenologis. Perilaku manusia dianggap sebagai sebuah tindakan yang memiliki makna, tujuan, atau gagasan dasar. Kenyataan atau realitas sosial ada dibalik setiap fenomena tindakan, sesuatu yang tidak tampak, berada di dasar pemikiran, yang bersifat noumena. Menurut Bogdan dan Taylor (1992:18-19) bahwa kaum fenomenologis mencari pemahaman lewat metode kualitatif seperti pengamatan berpartisipasi, wawancara terbuka, dan dokumen pribadi. 
Kenyataannya ilmu sosial atau sosiologi memang berbeda dengan ilmu alam. Ilmu alam mempelajari gejala alam, sedangkan sosiologi mempelajari gejala sosial yang sarat dengan makna-makna yang diberikan oleh para pelaku yang terjalin di dalamnya. Akibat dari cara berpikir demikian, maka metode ilmu sosial tidak pernah sama dengan ilmu alam. Ilmu sosial memperhitungkan makna yang mengalir di antara para pelaku yang terlibat dalam fenomena sosial. Ini adalah hal yang prinsip, sebagaimana dijelaskan Berger dan Kellner bahwa "fenomena manusia tidak dapat berbicara dengan sendirinya, melainkan harus dimaknai” (Berger dan Kellner dikutip oleh Samuel, 2012:44).

Adapun prosedur penelitian yang dilalui mengikuti empat tahapan yang disebutkan oleh Moleong (2006), yaitu tahap sebelum ke lapangan, tahap pekerjaan lapangan, tahap analisis data, dan tahap penulisan laporan. Sebelum turun ke lapangan, peneliti terlebih dahulu menyiapkan proposal penelitian, mengkonsultasikan usul penelitian, dan menyiapkan instrumen pendukung penelitian. Setelah itu peneliti akan segera turun ke lapangan. Pada tahap pekerjaan lapangan, peneliti akan mewawancarai sejumlah informan yang telah peneliti kenal sebelumnya. Pada tahap inilah sejumlah data yang dibutuhkan akan dikumpulkan baik melalui cara wawancara maupun observasi.

Setelah data-data yang dibutuhkan terkumpul peneliti akan melakukan proses analisis data. Sejumlah data yang terkumpul akan diinterpretasikan secara kritis dan mendalam sesuai dengan konteks permasalahan yang diteliti. Untuk menjamin keakuratan data maka akan dilakukan uji validitas data yang dilakukan dengan metode triangulasi. Terakhir adalah tahap penulisan laporan. Hasil penelitian akan ditulis berdasarkan data yang ditemukan di lapangan. Selain itu laporan ini juga akan dikonsultasikan kepada komisi pembimbing untuk dimintai saran dan masukan yang konstruktif.

\section{Unit Analisis}

Berdasarkan pemaparan pada pembahasan sebelumnya, selanjutnya dengan penyesuaian kondisi rill di situs penelitian, maka dapat dibentuk suatu unit analisis penelitian dengan memahami gejaka dan fenomena sosial yang timbul di masyarakat sebagai bentuk pembangunan investasi non fisik sebagai pemenuhan dalam keluarga memalui keberangkatan seseorang menjadi TKI di Kecamatan Selorejo Kabupaten Blitar, Melalui interaksi antara individu khususnya TKI dengan karakter yang menjadi penentu dalam keberangkatan seorang menjadi Tenaga Kerja Indonesia maka penelitian ini menggunakan pendekatan deduktif, yang berarti menentukan terlebih dahulu teori baku sebagai dasar analisis dari penelitian. Hal ini dimaksudkan untuk menghindari kekhawatiran saat realitas di lapangan tidak sesuai dengan teori yang ada.

\section{Penentuan Informan}

Berdasarkan pada penulisan sebelumnya telah dijelaskan pada dasarnya penelitian ini terpusat pada karakter yang menjadi pendorong seseorang menjadi TKI, dan karakter tersebut berupa karakter sosial-ekonomi yang tumbuh di tengah masyarakat (termasuk di dalam nya pihak-pihak secara langsung terlibat maupun pihak yang secara tidak langsung terlibat dalam interaksi tersebut). Berdasarkan penjelasan tersebut, informan yang dituju dalam proses pengambilan data penelitian ini adalah sebagai berikut :

1. Informan pertama, mantan pelaku migrasi internasional (TKI) yaitu seseorang yang pernah bekerja di luar negeri dan pada saat penelitian berlangsung sedang berada di lokasi penelitian, keluarganya, yang mampu memberikan informasi data terkait persepsi, sikap dan tindakannya ketika berhadapan dengan lingkungan dalam menetapkan keputusan-keputusan dalam kaitannya mengungkap pertimbangan karakter dasar (push factor) dalam pembentukan dan penyedia investasi non fisik sebagai pendorongan menjadi TKI.

2. Pihak-pihak lain yang diharapkan dapat memperoleh data sebagai uji validitas data, yang secara langsung ataupun tidak secara langsung terlibat dalam keputusan pertimbangan karakter sosial- ekonomi sebagai pendorongan menjadi TKI. Antara lain pihak aparat desa, kecamatan atau hal-hal lain yang mungkin bisa diperoleh dari perjalanan penelitian yang akan dilakukan.

\section{Uji Validitas}

Untuk mengecek keakuratan data, peneliti menggunakan metode triangulasi. Menurut Denzin (1970), dalam Marvasti, 2004), tujuan metode triangulasi adalah untuk meningkatkan validitas penemuan melalui pengumpulan data dari banyak perspektif. Dengan cara ini maka kesimpulan yang diambil didasarkan pada data-data yang dapat diuji kebenarannya.

Menurut Sugiyono (2008) triangulasi merupakan metode pengujian kredibilitas sebagai pengecekan data dari berbagai sumber dengan berbagai cara, dan berbagai waktu.

1). Triangulasi Sumber.

Triangulasi sumber untuk mengkaji kreadibilitas data dilakukan dengan cara mengecek data yang telah diperoleh melalui beberapa sumber, dalam penelitian ini sumber data melalui, TKI, PJTKI dan tokoh masyarakat setempat. Data dari ketiga sumber tersebut tidak dapat di rata-rata seperti penelitian kuantitatif, tetapi di deskripsikan, dikategorikan, mana pandangan yang sama, lalu di cek dengan observasi, dokumentasi, atau kuisioner. Bila dengan tiga teknik pengujian kreadibilitas data tersebut menghasilkan 
data yang berbeda, maka peneliti melakukan diskusi lebih lanjut kepada sumber data yang bersangkutan atau yang lain, untuk memastikan data mana yang dianggap benar.

2). Triangulasi Teknik.

Triangulasi teknik untuk mengkaji kreadibilitas data dilakukan dengan cara mengecek data kepada sumber yang sama dengan teknik yang berbeda. Misalnya data dari wawancara di cek dengan hasil data dari observasi, dokumentasi, atau kuisioner. Bila dengan tiga teknik pengujian kreadibilitas data tersebut, menghasilkan data yang berbeda-beda, maka peneliti melakukan diskusi lebih lanjut kepada sumber data yang bersangkutan atau yang lain, untuk memastikan data mana yang dianggap benar. Atau semuanya benar , karena sudut pandang yang berbeda.

3). Triangulasi Waktu.

Waktu juga sering mempengaruhi kreadibilitas data, data yang dikumpulkan dengan teknik wawancara di pagi hari pada saat nara sumber masih segar, belum banyak masalah, akan memberikan data yang valid sehingga lebih kredibel. Untuk itu dalam rangka pengujian kreadibilitas data dapat dilakukan dengan cara melakukan pengecekan dengan wawancara, observasi atau teknik lain dalam waktu dan situasi yang berbeda. Bila hasil uji menghasilkan data yang berbeda, maka dilakukan secara berulang sehingga ditemukan kepastian data.

\section{Hasil dan Pembahasan}

\section{Analisis Data}

Teknik analisis data yang digunakan dalam penelitian ini meminjam model analisis yang dikemukakan oleh Miles dan Huberman (1994), di mana kegiatan analisis data dibagi sebanyak tiga tahap, yaitu: tahap reduksi data, tahap penyajian data, dan tahap penarikan kesimpulan serta verifikasi. Alasan penggunaan model ini adalah karena sifatnya yang sangat sistematis dan detail dalam menjabarkan proses analisis data dari tahap awal hingga tahap akhir.

Dengan mengikutsertakan tahap pengujian validitas data dan informasi melalui metode triangulasi sebagai upaya pengafsahan data sehingga menjadi suatu informasi yang menarik dan dapat diuji kebenarannya sesuai penjelasaan metode triangulasi di penjelasan sebelumnya.

\section{Pembahasan}

Kecamatan Selorejo merupakan satu dari dua puluh dua Kecamatan yang membagi habis wilayah administrasi Kabupaten Blitar. Berada di wilayah Kabupaten Blitar di sebelah timur yang berbatasan wilayah dengan Kabupaten Malang. Berada di sebelah utara sungai Brantas yang membelah Kabupaten Blitar menjadi dua bagian. Bagian utara cendrung mempunyai struktur tanah yang lebih subur dari bagian selatan.

Adapula batas Kecamatan Selorejo adalah sebagai berikut, di sebelah barat berbatasan dengan Kecamatan Kesamben, sebelah utara berbatasan dengan Kecaamatan Doko, sebelaah timur berbatasan dengan Kabupaten Malang, sebelah selatan berbatasan dengan Kecamatan Kesamben dan Kabupaten Malang. Hal ini dapat dilihat pada gambar 4.1

Gambar 4.1.

Peta Kecamatan Selorejo

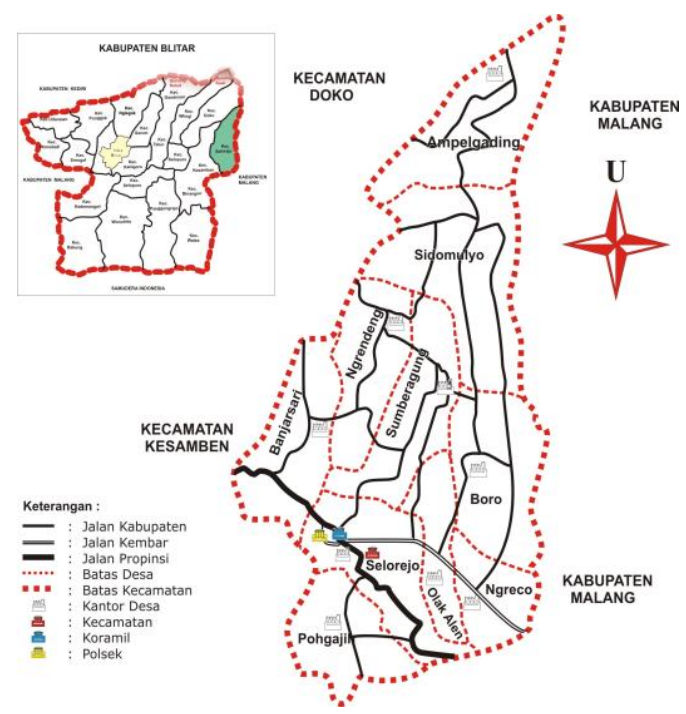

Sumber : Selorejo Dalam Angka, Diolah : 2016. 
Kecamatan Selorejo dengan luas wilayah 52,46 km2 dibagi menjadi 10 desa. Di antaranya yaitu Desa Pohgajih, Desa Selorejo, Desa Ngerco, Desa Boro, Desa Olakalen, Desa Sumberagung, Desa Banjarsari, Desa Ngrendeng, Desa Sidomulyo, dan Desa Ampelgading. Desa Sidomulyo merupakan desa yang terluas dengan luas $9,36 \mathrm{~km} 2$. . Dengan wilayah desa terkecil adalah Desa Ngerco dengan luas wilayah 2,37km2 atau hanya $4,52 \%$ dari luas wilayah Kecamatan.

Berdasarkan pemutakhiran Master File Desa BPS Kebupaten Blitar, Kecamatan Selorejo terbagi dalam 10 Desa, 25 Dusun, 76 RW, 269 RT. Berdasarkan (Kabupaten Blitar Dalam Angka: 2013), dari pendataan registrasi jumlah penduduk di Kecamatan Selorejo di tahun 2012 sebesar 44612 jiwa dengan mayoritas beragama islam.

\section{Karakteristik sosial TKI Kecamatan Selorejo}

Karakter Sosial TKI di Kecamatan Selorejo dilihat dari a) karakter individu, TKI di Kecamatan Selorejo memiliki jenis kelamin perempuan yang banyak dibutuhkan menjadi TKI di Luar Negeri, dengan usia yang produktif, yang memiliki status tempat tinggal TKI secara umum masih belum banyak memiliki rumah sendiri, namun status tempat tinggal banyak yang masih bergabung bersama dengan orang tua, status perkawinan TKI yang berangkat ke luar negeri memiliki status sudah menikah, TKI memiliki pendidikan rata-rata pendidikan menengah (SMP) dan SMA, pasangan hidup (suami atau istri) memiliki usia produktif dan pendidikan rata-rata memiliki pendidikan tinggi sebagai pendorong hidup sejahtera dan sebagaian besar memiliki pekerjaan sebagai wiraswasta.

Karakter rumah tangga, menunjukkan bahwa secara keseluruhan tanggungan keluarga TKI di Kecamatan Selorejo relatif besar, karena beban tanggungan TKI memiliki lebih dari 5 orang tanggungan yang berasal dari keluarga inti maupun di luar keluarga inti. Selain, itu faktor pendidikan anak juga mempengaruhi seseorang menjadi TKI, karena biaya yang dikeluarkan untuk pendidikan juga memerlukan biaya yang tinggi. Fenomena berkaitan karakter rumah tangga dengan semakin besarnya tanggungan anak, tanggungan atas investasi non fisik berkaitan dengan pendidikan anak serta banyaknya jumlah tanggungan yang menjadi beban keseluruhan bagi para TKI di Kecamatan Selorejo, tidak dapat dipungkiri, bahwa akan semakin mendorong seseorang untuk berangkat menjadi TKI.

Karakter wilayah, alasan menjadi TKI, atau TKI berangkat ke Luar Negeri adalah Pertama, permasalahan ekonomi dalam rumah tangga yang memiliki penghasilan yang kecil, Kedua, ingin mencari permodalan dan Ketiga, membantu meringankan beban keluarga. Keempat, gaji di Luar Negeri lebih besar dibanding bekerja di Dalam Negeri, Kelima, sulitnya mencari pekerjaan di Desa, sehingga seseorang memilih bekerja ke Luar Negeri. TKI Kecamatan Selorejo menjadi menjadi TKI memiliki jumlah keberangkatan yang bervariatif ada yang hanya 1 kali dan ada pula yang 2 kali berangkat menjadi TKI, namun kebanyakan jumlah keberangkatan 1 hingga 2 kali keberangkatan, sebagai akumulasi pengummpulan modal usaha.

Negara tujuan keberangkatan yang menjadi minat TKI Kecamatan Selorejo Hongkong, Taiwan dan Malaysia, dan lama menjadi TKI sesuai dengan kontrak yaitu sekitar 4 sampai 5 tahun. jenis pekerjaan yang banyak dibutuhkan adalah pekerjaan tenaga kerja informal seperti pembantu rumah tangga, serta sumber informasi keberangkatan banyak bersumber dari teman dan tetangga, dan alur keberangkatan dan syarat-syarat menjadi TKI secara rinci dan jelas dalam peraturan yang dikeluarkan Dinas Tenaga Kerja Kabupaten Blitar serta melalui alur proses rekruitmen dari PJTKI, dan Yang dilakukan di Negara Tujuan setelah sampai di Negara Tujuan. Secara umum, TKI akan ditampung di agensi terlebih dahulu untuk melakukan general check up, setelah itu baru TKI di antarkan ke majikan oleh agensi, struktur penentuan tujuan negara keberangkatan, sumber informasi mendapat dari teman-teman, tetangga, atau saudara TKI yang ada di Negara tujuan dan ada pula teman-teman, tetangga, atau kerabat yang pernah menjadi TKI atau ex-TKI.

Karakter Ekonomi, dilihat dari sisi tingkat upah, TKI selama bekerja di luar negeri sudah cukup untuk memenuhi kebutuhan TKI di luar negeri dan dapat memenuhi keluarga TKI di Indonesia. Dilihat dari, tingkat upah secara rinci adalah sebagai berikut: sistem pembayaran upah Sistem pembayaran upah, secara umum langsung diterima dari majikan TKI. Upah yang diterima bervariatif seperti Informan TKI indah 3500 dollar Hongkong perbulan (Negara Hongkong), Dari informan antara lain (1) Syukur 12001500 ringgit (Negara Malaysia), (2) Kusrini 4.500.000 rupiah uang dengan kurs Indonesia (Negara Taiwan), dan (3) Linda 2.500 dollar Hongkong (Negara Hongkong) Prosentase(\%) bagi hasil upah setiap bulan pada PJTKI 70 sampai 80 persen. Penetapan upah di daerah keberangkatan TKI penetapan upah di daerah keberangkatan TKI yaitu pada saat di Indonesia telah dijelaskan mengenai pembayaran upahnya;

\section{Investasi Non Fisik Sebagai Push Factor TKI}

Makna migrasi bagi TKI masyarakat Kecamatan Selorejo secara umum meliputi tiga makna tujuan utama yaitu sebagai berikut: (i) TKI melakukan migrasi ke luar negeri senantiasa untuk mendapatkan pekerjaan, ditengah sulitnya mendapatkan pekerjaan di dalam negeri (ii) TKI melakukan migrasi keluar 
negeri senantiasa untuk meningkatkan kesejahteraan (welfare) dalam hal peningkatan pendapatan atau penghasilan.(iii) Pada makna ke tiga ditemui bentuk fenomena yang menarik dimana sebagian besar TKI memilih menjadi tenaga kerja migran sebagai pemenuhan kebutuhan keluarga dalam hal ini memenuhi kebutuhan investasi non fisik seperti pendidikan dan kesehatan

TKI di Kecamatan Selorejo dengan informan yang dikaji memiliki informasi dimana ekspektasi yang tinggi terhadap keberhasilan seseorang akan mendorong seseorang tersebut untuk pemenuhan tingkat utilitas hidup yang tinggi. Ketika sebagian dari informan yang bertindak sebagai Ibu rumah tangga dalam suatu keluarga mengambil keputusan menjadi seorang TKI, sebagai bentuk emansipasi dalam usaha pengembangan kualitas hidup keluarga. Walaupun terkadang informan telah memiliki pekerjaan atau wiiraswasta, dorongan ekspektasi akan pemenuhan kewajiban hidup yang tinggi, antara lain; penddikan anak, kebutuhan sehari-hari keluarga, dan membangun usaha baru sebagai alasan motivasi menjadi TKI. Hingga akhirnya informan memiliki 2 (dua) usaha baru dengan penambahan modal yang harapannya dapat meningkatkan usaha, yang secara bersamaan akan mendorong pada perubahan kehidupan TKI dalam memenuhi biaya pendidikan anak bahkan sebagian besar TKI berangkat hingga dua kali demi terkumpulnya biaya dan menunda keberangkatan pada saat fokus terjadi dalam hal mendampingi pendidikan putra dan putri nya di bangku pendidikan.

\section{Kesimpulan dan Saran}

Disini dijabarkan tiga komponen, yaitu: kesimpulan, saran dan kontribusi serta keterbatasan penelitian.

\section{Kesimpulan}

Ditengah sulitnya lapangan pekerjaan akan permintaan tenaga kerja di Kecamatan Selorejo, peran investasi non fisik bagi informan menjadi TKI senantiasa untuk menghidupi kebutuhan rumah tangga dengan perhitungan jumlah tanggungan keluarga, tidak menutup kemungkinan ketika seorang ibu rumah tangga ikut membantu meringankan beban suami yang memiliki tanggungjawab atas keluarga dan berupaya untuk membiayai pendidikan anak yang tumbuh kembang, sehingga kelak anak atau keluarga dapat menempuh jenjang kehidupan yang lebih tinggi. Makna migrasi bagi informan lebih memprioritaskan dalam investasi non fisik dan modal usaha dalam pengembangan usaha keluarga.

Kebutuhan ekonomi, menjadi masalah fundamental bagi TKI ditunjukkan dengan semakin banyaknya kebutuhan dalam pemenuhan beban keluarga. Pendapatan yang diterima pada saat pekerjaan pertama sebelum menjadi TKI relatif kecil dan kurang mencukupi untuk memenuhi kebutuhan hidup keluarga, sehingga terdorong seseorang untuk menjadi TKI. Potret yang ditangkap dari informan

Penelitian ini menemukan bentuk mobilitas horizontal, dalam kajian dimana informan melakukan perpindahan dari satu wilayah ke wilayah lain dengan berbagai alasan seperti, pemenuhan modal yang dilakukan oleh informan dalam membantu usaha keluarga yang dilakukan oleh informan. Walaupun alasan berbeda secara wilayah informan melakukan mobilitas horizontal.

PJTKI memiliki peranan yang penting terkait dengan jaringan wilayah dan jaringan migran, dengan memberi wawasan kepada TKI berupa, bahasa, situasi di Negara tujuan, budaya, keterampilan kerja sebagai peningkatan kapasitas dan kualitas sumber daya manusia untuk menjadi seorang Tenaga Kerja Indonesia. Serta, melakukan seleksi kemampuan melalui ketetapan syarat-syarat menjadi TKI dan penilaian kelayakan keberangkatan yang dilakukan PJTKI pada saat jenjang waktu pelatihan kepada calon TKI.

\section{Implikasi}

Penelitian ini memiliki impilikasi atau pengaruh terhadap bentuk kebijakan atau saran yang ditujukan kepada Pemerintah Daerah, khasanah keilmuan dan khalayak yang berkempetingan dalam perumusan kebijakan tenaga kerja migran sebagai bentuk perlu adanya dorongan berupa pembinaan dari pemerintah daerah dalam hal ini Dinas Koperasi dan UMKM Kabupaten Blitar untuk mewadahi para TKI yang melakukan usaha-usaha baru setelah pulang dari luar negeri.

Memberikan informasi akan perlu adanya pencatatan yang dilakukan oleh pihak Pemerintah Desa dan pihak Kecamatan Selorejo berkaitan dengan mengenai keberangkatan dan kembalinya TKI ke Indonesia, sebagai upaya untuk menghindari TKI dan PJTKI yang ilegal sebagai bentuk pengawasan dari sisi administrasi yang didukung oleh Dinas Tenaga Kerja dan Transmigrasi.

Penelitian ini diharapkan menjadi masukan bagi perencanaan tenaga kerja baik nasional maupun daerah yang tepat, yang akan dapat memperkirakan kebutuhan tenaga kerja untuk daerah tertentu, pada 
sektor tertentu, pada waktu tertentu untuk keahlian tertentu dan atau juga sebaliknya. Secara umum terjadinya pengangguran merupakan akibat dari masalah pasar kerja, tenaga kerja, dan kesempatan kerja dan selanjutnya diperlukan sinergi antara permintaan dan penawaran tenaga kerja yang diwadahi oleh perencanaan tenaga kerja nasional maupun daerah.

\section{Ucapan Terimakasih}

Pada kesempatan ini disampaikan terima kasih kepada pihak Universitas Muhammadiyah Malang dalam hal ini Dekan Fakultas Ekonomi yang telah memberikan dukungan pendanaan penelitian sehingga penelitian dapat diselesikan. Selain itu kami ucapkan terimakasih atas pihak yang terlibat seperti mahasiswa, dosen dan karyawan yang telah memberikan dukungan pemikiran sehingga penelitian ini dapat berjalan dengan tanpa terkendala. Tidak lupa kamu mengucapkan terimakasih atas kerja sama dengan pihak yang terkait seperti Kecaamatan Selorejo, PJTKI, dan masyarakat Kecamatan Selorejo dalam partisipasi penelitian ini.

\section{Referensi}

Purwanti, Putu Ayu Pramitha. 2009. Analisis Kesempatan Kerja Sektoral di Kabupaten Bangil Dengan Pendekatan Pertumbuhan Berbasis Ekspor. Jurusan Ekonomi Pembangunan Fakultas Ekonomi Universitas Udayana, Denpasar: Piramida.

J.Simanjuntak, Payaman. 1998. Pengantar Ekonomi Sumber Daya Manusia, Edisi Kedua. Jakarta: Lembaga Penerbit Fakultas Eonomi Universitas Indonesia.

Sumarsono, Sonny. 2003. Ekonomi Manajement Sumber Daya Manusia dan Ketenagakerjaan, Cetakan Pertama. Yogyakarta: Graha Ilmu.

Sumarsono, Sonny. 2009. Teori dan Kebijakan Publik Ekonomi Sumber Daya Manusia, Edisi Pertama. Yogyakarta: Graha Ilmu.

Todaro, Michael. 1994. Pembangunan Ekonomi. Jakarta. Erlangga.

Todaro Michael. 1998. Pembangunan Ekonomi di dunia ke 3. Jakarta. Erlangga. Undang-Undang Republik Indonesia Nomer 39 Tahun 2014 Tentang Penempatan dan Perlindungan Tenaga Kerja Indonesia di Luar Negeri. di unduh 11 januari 2015 di www.Hukumonline.com.

Marvasti B.Amir. 2004. Qualitative Research in Sociology. Stage Publications, London.

Burrell, Gibson and Morgan.1979. Sociology Paradigma and Organisational Analysis. FS2EK, London.

Bogdan, R. dan Taylor, J. S.1992. Introduction to Qualitative Research Methods: A Phenomenological Approach to the Social Sciences. Arief Furchan (penerjemah). Pengantar Metoda Penelitian Kualitatif. Surabaya: Usaha Nasional.

Moleong, Lexy.2006. Metodologi Penelitian Kualitatif. Bandung: PT. Remaja Rosda Karya.

Parera, M. F., Berger, P. L., and Luckmann, T. 2012. The Social Construction of Social Reality: A Treatise in Socilology of Knowledge. Hasan Basri (penerjemah) Tafsir Sosial atas Kenyataan Risalah tentang Sosiologi Pengetahuan. Jakarta: LP3ES.

Sugiyono. 2008. Metode Penelitian Kuantitatif, Kualitatif dan R \& D. Bandung: Alfa Beta.

Miles, Huberman. 1994. Qualitative Data Analysis. SAGEPUBLICATION, London. 